\title{
Enzymatic cleaning of biofouled thin-film composite reverse osmosis (RO) membrane operated in a biofilm membrane reactor
}

\author{
Authors: Mohiuddin Khan, Steffen Danielsen, Katja \\ Johansen, Lindsey Lorenz, Sara Nelson, \& Anne \\ Camper
}

This is an Accepted Manuscript of an article published in Biofouling on June 2014, available online: http://www.tandfonline.com/10.1080/08927014.2013.852540"

Khan M, Danielsen S, Johansen K, Lorenz L, Nelson S, Camper A, "Enzymatic cleaning of biofouled thin-film composite reverse osmosis (RO) membrane operated in a biofilm membrane reactor," Biofouling, June 2014 30(2):153-67. 


\section{Enzymatic cleaning of biofouled thin-film composite reverse osmosis (RO) membrane operated in a biofilm membrane}

\section{reactor}

Mohiuddin $\operatorname{Khan}^{\mathrm{a}, \mathrm{b}_{*} \text {, Steffen Danielsen }}{ }^{\mathrm{c}}$, Katja Johansen ${ }^{\mathrm{c}}$, Lindsey Lorenz ${ }^{\mathrm{b}}$, Sara Nelson ${ }^{\mathrm{d}}$ and Anne Camper ${ }^{b_{*}}$

${ }^{\mathrm{a}}$ Department of Chemical Engineering and Bioengineering, Washington State University, Pullman, WA, USA; ${ }^{\text {Department of Civil }}$ Engineering, Center for Biofilm Engineering, Montana State University, Bozeman, MT, USA; ${ }^{C_{N}}$ Novozymes A/S, Bagsvaerd, Denmark;

Institute for Systems Biology, Seattle, WA, USA

Application of environmentally friendly enzymes to remove thin-film composite (TFC) reverse osmosis (RO) membrane biofoulants without changing the physico-chemical properties of the RO surface is a challenging and new concept. Eight enzymes from Novozyme A/S were tested using a commercially available biofouling-resistant TFC polyamide RO mem-brane (BW30, FilmTech Corporation, Dow Chemical Co.) without filtration in a rotating disk reactor system operated for 58 days. At the end of the operation, the accumulated biofoulants on the TFC RO surfaces were treated with the three best enzymes, Subtilisin protease and lipase; dextranase; and polygalacturonase (PG) based enzymes, at neutral $\mathrm{pH}(\sim 7)$ and doses of 50,100 , and $150 \mathrm{ppm}$. Contact times were 18 and 36 h. Live/dead staining, epifluorescence micros-copy measurements, and $5 \mu \mathrm{m}$ thick cryo-sections of enzyme and physically treated biofouled membranes revealed that Subtilisin protease- and lipasebased enzymes at $100 \mathrm{ppm}$ and $18 \mathrm{~h}$ contact time were optimal for removing most of the cells and proteins from the RO surface. Culturable cells inside the biofilm declined by more than five logs even at the lower dose $(50 \mathrm{ppm})$ and shorter incubation period $(18 \mathrm{~h})$. Subtilisin protease- and lipasebased enzyme cleaning at $100 \mathrm{ppm}$ and for $18 \mathrm{~h}$ contact time restored the hydrophobicity of the TFC RO surface to its virgin condition while physical cleaning alone resulted in a $50^{\circ}$ increase in hydrophobicity. Moreover, at this optimum working condition, the Subtilisin protease- and lipasebased enzyme treatment of biofouled RO surface also restored the surface roughness mea-sured with atomic force microscopy and the mass percentage of the chemical compositions on the TFC surface estimated with X-ray photoelectron spectroscopy to its virgin condition. This novel study will encourage the further development and application of enzymes to remove biofoulants on the RO surface without changing its surface properties.

Keywords: thin-film composite reverse osmosis membrane; enzymatic cleaning; biofouling; polygalacturonases, protease, lipase and dextranase; surface property characterization

\section{Introduction}

The application of the thin-film composite (TFC) reverse osmosis (RO) membranes for water treatment has increased significantly over the last two decades due to stringent water quality standards and the scarcity of highquality source/raw waters. This has led to the increased importance of treating more impacted water sources to produce potable water. The treatment of lower quality water, including wastewater and seawater/brack-ish waters, can lead to biofouling of RO membranes. Biofouling is one of the least understood and controlled fouling mechanisms, and the multiplication of cells and simultaneous production of extracellular polymeric substances (EPS) inside the biofoulants on the mem-brane decreases membrane productivity (Ridgway HF \& Flemming H-C 1996; Herzberg et al. 2009). Bacteria in natural and engineered aquatic systems are ubiquitous, and the subsequent formation of biofilm biomass consisting of structured microbial communities and their byproducts is inevitable (Costerton et al. 1995; Flemming et al. 1997; Donlan 2002; Stoodley \& Stoodley 2002). Colloidal and particulate fouling can be reduced using pretreatment options (Ridgway HF \& Flemming H-C 1996); however, in practice, removing all microorganisms is not possible and the few that pass the barrier of the pretreatment system can adhere to the membrane, grow, and form biofilm, which affects system performance.

Fouling requires frequent chemical cleaning, which ultimately shortens membrane life, thus increasing the operation and maintenance costs of the RO membrane plants. A decline in permeate flux can be directly related to an increase in operation costs and can trigger the need for periodic chemical cleaning, which requires additional manpower and chemicals, and ultimately results in the premature replacement of the membrane (Maartens et al. 2002). Long-term flux decline in RO is primarily due to membrane fouling (Wiesner \& Aptel 1996) and is usually caused by the deposition of feedwater components 
rejected by the membrane (sparingly soluble inorganic compounds, colloidal or particulate matter, and dissolved organics), or by the attachment and growth of microorganisms on the membrane surface (Speth et al. 2000). Furthermore, biofouling can alter surface chemistries, narrowing down the flow channels across the RO and nanofiltration surfaces (Kwak \& Thm 1999; Khan et al. 2010). It is reasonable to assume that biofouling of the RO membranes is ubiquitous and it is important to deal with this process rather than expect that it can be prevented.

Several cleaning options are currently available to treat biofilm formation on affected membranes in an attempt to recoup an acceptable level of permeate flux. In laboratory-scale studies, the induction of an electrical field may be used to reduce the influence of a layer of polarized biofoulants (Brunner \& Okoro 1989; von Zumbusch et al. 1998; Iritani et al. 2000; Weng et al. 2005; Tarazaga et al. 2006), and higher electric charge density may kill microorganisms, which also biodegrade several compounds in the system (Weng et al. 2005; Tarazaga et al. 2006). Alkaline solutions are used to clean organically fouled membranes using hydrolysis and solubilization (Thurman 1985). EDTA, a metal chelating agent, can also be used as a supportive treatment to aid in the improved cleaning of fouled membranes. Surfactants, compounds containing both hydrophilic and hydrophobic compounds, solubilize foulants on membrane surfaces (Hong \& Elimelech 1997). Surfactants, such as sodium dodecyl sulfate (SDS), create a micelle around organic foulants, resulting in the solubilization of macromolecules and subsequent membrane flux restoration (Rosen 1989). $\mathrm{NaOH}$, an alkaline reagent, has been used in several studies to restore membrane permeability after the occurrence of biofouling and has proven reliable in the removal of organic matter from the membrane surface (Ang et al. 2006). The removal of organic matter from membrane surfaces has also been investigated through the use of $\mathrm{NaClO}$ (Kimura et al. 2004). Salt or even seawater has been recommended to clean organic foulants from RO surfaces (Lee \& Elimelech 2007); however, seawater itself causes or enhances scaling of RO surfaces (El-Dahshan 2001; Hasson \& Semiat 2006). A common concern with most of these cleaning agents is their adverse impact on the environment when discharged in waste streams. Physical cleaning methods are also available for the treatment of fouled membranes and include vibration, air sparge, hydraulic cleaning, and $\mathrm{CO}_{2}$ back permeation (Platt \& Nystrom 2008).

Unfortunately, chemical and physical treatment of foulants can damage the membrane surface by changing the membrane surface composition, surface hydrophobicity, and surface roughness (Platt \& Nystrom 2008). These changes can have a detrimental effect on permeate flux and the salt rejection qualities of the membrane, limiting the filtration efficiency. Furthermore, the cleaning mode and action of these physico-chemical agents on biofoulant removal efficiency and the RO membrane surface properties have not been well described.

The use of enzymatic cleaners is of interest because they operate in mild conditions, which is a positive factor for their application to the cleaning of membranes sensitive to chemicals, $\mathrm{pH}$, and/or temperature (Argüello et al. 2005). Enzymes are environmentally friendly natural products that not only improve cleaning efficiency, but also reduce the amount of chemicals needed and the energy costs (Chen et al. 2006). Neutral pH enzymebased cleaners have been marketed as an altemative method for cleaning RO/UF systems. EPS are major components of membrane bioreactor biofoulants and enzymes have been investigated as a common cleaning agent to overcome EPS protein foulants (Puspitasari et al. 2010). It was assumed that enzymes cleave the proteins into pieces small enough to be rinsed from the system (Allie et al. 2003). In several studies (Allie et al. 2003; Argüello et al. 2003; Chen et al. 2006), enzymes were used to clean organic foulants from ultrafiltration (UF) membranes in the dairy industry.

Based on the above observations, it was hypothesized that different natural polygalacturonases (PG), and protease-, lipase-, and dextranase-based enzymes would efficiently remove biofoulants from RO surfaces without altering the membrane surface properties. To the best of the authors' knowledge, the effects of enzymes extracted from different microorganisms, plants, and other sources that are widely used in dishwashing detergents, cosmetics, food processing, skin care ointments, and contact lens cleaners have not been tested on RO membrane biofoulant removal. A model system was used to test the efficacy of eight enzyme formulations for removing biofoulants on a commercially available RO membrane. The three most effective enzymes were selected for further optimization for biofilm removal. The objectives of this study were to: (1) investigate the mode of action of enzymatic cleaning of TFC RO membrane biofoulants and (2) characterize the effects of the enzymes on membrane surface properties.

\section{Materials and methods}

\section{Membrane type and reactor setup}

To observe biofilm formation and its impact on RO membrane surfaces, commercially available polyamide aromatic TFC RO (Dow BW30) membranes (FilmTec Corporation, Dow Chemical Company, USA) were used. Detailed information about the heterogeneity and chemistry of this surface and of the aromatic groups on the TFC surface is proprietary. The general performances of this surface include $125 \mathrm{psi}$ applied pressure and $2,000 \mathrm{ppm}$ initial concentration of $\mathrm{NaCl}$ in DI water. The membrane productivity and water permeability 
coefficient $/ \%$ salt passage ( $A$-value $/ \%$ SP) ratio were $32 \mathrm{gfd}\left(5.4 \mathrm{~cm} \mathrm{~h}^{-1}\right)$ and 0.16 , respectively. $\mathrm{NaCl}$ rejection was $-99.6 \%$.

The biofilm formation study was carried out in three rotating disk reactor (RDR) systems (Biosurface Technologies Corporation, USA) (Supplementary Figure S1 [Supplementary material is available via a multimedia link on the online article webpage]). Each reactor contained six separate, removable polycarbonate coupons $(12.7 \mathrm{~mm}$ in diameter). The RO membrane swatches were cut from flat sheet rolls and boiled in nanopure water for $10 \mathrm{~min}$ (according to the manufacturer's instructions, which removed the residual chemicals and any surface contamination and did not change the surface structures and chemistries of these membranes). After cooling to room temperature and prior to use, the membranes swatches were washed several times with nanopure water. The membrane swatches were adhered onto removable polycarbonate coupons with silicon rubber sealant (Dow Coming, USA) and placed in the rotor of the RDR. The RDR has a variable speed rotating drum, an operating volume of $250 \mathrm{ml}$, and a high surface area to volume ratio. The diameter of the rotor disk was $7.0 \pm 0.2 \mathrm{~cm}$ which contained six evenly spaced holes with a diameter of $1.27 \pm 0.1 \mathrm{~cm}$. Six polycarbonate coupons can be placed into the holes. The center of each hole was located $2.55 \pm 0.03 \mathrm{~cm}$ from the center of the disk. The details about the RDR have been discussed elsewhere (Khan et al. 2010).

The reactors were fed continuously with Bozeman (Montana, USA) tap water that flowed through a granular activated carbon column and a biologically activated carbon (BAC) column operated in up-flow mode as a source of indigenous microorganisms. These columns remove the majority of the background carbon from the tap water. Some important water quality parameters (average values) of Bozeman tap water during this study were mentioned in a previous study (Khan, Stewart, et al. 2011). To enhance the growth of biofilm, the biologically treated water was amended with nutrients (C:N:P) (equimolar concentrations of glutamic acid, glucose, galactose, and arabinose were used for carbon source; $\mathrm{KNO}_{3}$ and $\mathrm{K}_{2} \mathrm{HPO}_{4}$ were used for nitrogen and phosphorous source, respectively). These ( $\mathrm{C}, \mathrm{N}$, and $\mathrm{P})$ were added to the reactors at a 100:10:1 (molar ratio) basis. Specifically, $5.54 \mathrm{ml}$ of carbon, $16.88 \mathrm{ml}$ of nitrogen, and $4 \mathrm{ml}$ of phosphorus were added to a 201 container of autoclaved nanopure water. The rotation speed of the rotor in the RDR was $50 \mathrm{rpm}(0.071 \times g)$ and the hydraulic retention time was $3.5 \mathrm{~h}$ in all reactors. The average shear stress on the RO surfaces was maintained at $\sim 6.72 \mathrm{~Pa}$. The temperature was ambient $(25 \mathrm{C})$ and $\mathrm{pH}$ was $7-8$. The reactors were operated continuously for 58 days to ensure satisfactory and thicker biofilm growth. The operating conditions and analyses are shown in Table 1 . The colony forming units
Table 1. The operating conditions of the RDR systems.

\begin{tabular}{|c|c|}
\hline Operating conditions & Parameters and values \\
\hline Period of run & 58 days \\
\hline Sampling frequency & At the end of run \\
\hline $\begin{array}{l}\text { Average CFU ml }{ }^{-1} \text { in } \\
\text { BAC treated water }\end{array}$ & $(1.08-1.52) \times 10^{4}$ \\
\hline Membrane assays & $\begin{array}{l}\text { Images of live/dead cells on RO } \\
\text { membrane before and after enzyme } \\
\text { treatment; cryo-sectioning of } \\
\text { biofoulants on membrane with and } \\
\text { without treatment; culturable cell } \\
\text { counts in suspension during } \\
\text { treatment; contact angle analysis of } \\
\text { RO surface at virgin condition and } \\
\text { after treatment; AFM images and } \\
\text { XPS analysis of RO surfaces before } \\
\text { and after treatment }\end{array}$ \\
\hline $\begin{array}{l}\text { Nutrient condition } \\
\text { (C:N:P) }\end{array}$ & $\begin{array}{l}1.5 \mathrm{mg}^{-1} \text { of C: } 0.18 \mathrm{mg} \mathrm{I}^{-1} \text { of } \\
\mathrm{N}: 0.04 \mathrm{mg} \mathrm{I}^{-1} \text { of } \mathrm{P}\end{array}$ \\
\hline Flow rate of nutrient & $42 \%$ of total influent flow-rate \\
\hline $\begin{array}{l}\text { Flow rate of BAC } \\
\text { treated water }\end{array}$ & $58 \%$ of total influent flow-rate \\
\hline
\end{tabular}

Note: Three RDRs were operated simultaneously. The biofouled RO membrane samples in RDR-1, RDR-2, and RDR-3 were used for Subtilisin protease and lipase, dextranase, and PG based enzyme treatments, respectively.

(CFU) in the BAC water were measured using R2A agar (Fisher Scientific, IL) plated in triplicate.

Membrane swatch sampling was done at the end of the operational period. The membranes were carefully removed from the coupons using a sterilized razor blade and hemostat without disturbing the biofilm. The surfaces with biofoulants were cut into sections with sterilized scissors for membrane and biofilm assays.

\section{Enzyme treatment}

The stock enzymes (Table 2) developed and provided by the Novozymes A/S, Denmark, were diluted using autoclaved and then filtered (through 0.2 PVDF disc filter, Millipore, USA) nanopure water at neutral $\mathrm{pH}$ at room temperature to final concentrations of 50,100 , and $150 \mathrm{ppm}$. Detailed information about the composition, characteristics, biodegradability, and chemistry of these enzymes is proprietary. The RO membrane swatches were removed from the RDR after biofilm formation and soaked in diluted enzymes for either 18 or $36 \mathrm{~h}$ with the exception of the membrane on coupon \#1 and \#6 (positive controls). The swatches of positive control membranes with biofoulant and those following cleaning of the biofoulants with nanopure water and a sterilized soft rubber scrubber (VWR, Denver) were used for other assays as discussed below. In a previous study (Khan et al. 2010), there was no change in surface morphology and chemical compositions during this physical cleaning 
Table 2. The active components, sources, and enzyme commission (EC) numbers of Subtilisin protease and lipase, dextranase, and PG based enzymes.

\begin{tabular}{lll}
\hline $\begin{array}{l}\text { Enzyme } \\
\text { number in } \\
\text { this study }\end{array}$ & $\begin{array}{l}\text { Active components } \\
\text { and sources }\end{array}$ & EC numbers \\
\hline E \#1 & $\begin{array}{l}\text { Mixture of Subtilisin } \\
\text { protease and lipase. The } \\
\text { proteinase is from Bacillus } \\
\text { lentu and the lipase is from }\end{array}$ & $\begin{array}{l}\text { EC } 3.4 .21 .62 \text { and } \\
\text { protease and } \\
\text { lipase, respectively }\end{array}$ \\
& $\begin{array}{l}\text { Humicola lamuginosus } \\
\text { Dextranase (1,6- } \alpha \text {-D-Glucan } \\
\text { 6-glucanohydrolase) from }\end{array}$ & EC 3.2.1.11 \\
& $\begin{array}{l}\text { Paecilomyces lilacinus - } \\
\text { recombinantly expressed in } \\
\text { Aspergillus oryzae }\end{array}$ & \\
E \#3 & $\begin{array}{l}\text { PG - a multi-component } \\
\text { composition containing at } \\
\text { least four different PGs }\end{array}$ & EC 3.2.1.15 \\
\hline
\end{tabular}

procedure of virgin membranes. After incubation and cleaning with the enzymes, the membrane swatches were air dried for $1 \mathrm{~h}$ without further cleaning prior to membrane assays parallel to the control membrane (swatches on coupon \#1 and \#6) and also virgin RO surface assays. During incubation of membranes with the enzyme, ambient temperature and neutral $\mathrm{pH}$ were maintained.

\section{Membrane assay and analytical method}

The RO membrane swatches before and after cleaning the biofoulants were examined using different biochemical analyses. The analyses were repeated in replicate experiments and $p$ values were calculated using a two-tailed Student's $t$ test. The RO membrane swatches after enzymatic cleaning of the biofoulants were used for contact angle measurement, atomic force microscopy (AFM), and X-ray photoelectron spectroscopy (XPS) analyses. However, for an additional assay in XPS analysis, a control RO membrane swatch with biofoulants was physically cleaned using nanopure water and soft rubber scrubber, as described before. The cleaned RO swatches were then dried at room temperature for 2-3 h. Before contact angle, AFM, and XPS analyses, the RO membrane surfaces were dried again under nitrogen gas for $1 \mathrm{~min}$. Parallel control (virgin) membranes that had not been subjected to biofouling were also analyzed.

\section{Visualization of live and dead cells in the biofoulants on RO membrane swatches}

The LIVE/DEAD BacLight ${ }^{\text {TM }}$ Bacterial Viability Kit (Invitrogen/Molecular Probes, Oregon) was used for staining live and dead cells on the surface of the RO membranes. Equal amounts $\left(1.5 \mu 1 \mathrm{ml}^{-1}\right)$ of SYTO 9
(3.34 mM) and propidium iodide $(20 \mathrm{mM})$ dyes were diluted in $1 \mathrm{ml}$ of nanopure water and after proper dilution and vortexing; dyes were added to the top surface of the membrane and incubated for $1 \mathrm{~h}$ in the dark. After incubation, the excess dye was carefully washed off with nanopure water, and the stained cells were observed under an epifluorescence microscope (Nikon, Eclipse E 800, Japan) with a Nikon $100 \times$ objective lens. Fifteen to 20 images of live and dead cells in the top layer of biofilm on the membrane surfaces were captured and analyzed with the MetaMorph software (Molecular Devices Corporation, USA).

\section{Cryo-sectioning of the membranes}

For the cryo-sectioning, the RO membranes with biofoulants and after cleaning were stained following the same procedures as for the live/dead imaging. After washing off the excess dye with nanopure water, biofoulants on the top of membranes were frozen within 2-3 min after being flooded with the optimum cutting temperature liquid (Sakura Finetek USA, CA) keeping the inactive membrane surfaces (which were used to adhere onto the coupon) on a metal plate over a dry ice block. A cryostat (Leica CM 1850, Germany) was used to cut $5.0 \mu \mathrm{m}$ sections through the biofilm. The sectioned layer of the biofoulants and membranes was placed on a positively charged microscope slide (Fisher Scientific, IL) and observed under the epifluorescence microscope with a Nikon $20 \times$ objective lens. The cryo-sections of stained biofilms on membranes were analyzed with MetaMorph software to calculate the regions of live/dead cells and the thickness of accumulated biofoulants on the membrane surfaces. Each image has a distribution of live (green) and dead (red) cells along the thickness of biofilm on the membrane.

A line scan was done with the MetaMorph software across the slices of membranes with biofoulants. Each line scan generated two profiles depending on the location of live and dead cells trapped inside the biofilms. The detailed procedure has been discussed in a previous report (Khan, Stewart, et al. 2011). For each membrane swatch, 10-15 slices of membranes were imaged (three images per slice), and from each image five different line scans were generated for analysis.

\section{Culturable cell counts of microorganisms in suspension after removing from biofoulants}

The accumulated organisms in the biofoulants on the RO swatches removed from the surface either by enzyme treatment or nanopure water (for control samples), as discussed above, were centrifuged first at 5,000 rpm and then pellets were resuspended in $10 \mathrm{ml}$ of nanopure water. Finally, the pellets were dispersed by homogenizing (Biohomogenizer, Biospec Products Inc., Bartlesville, OK) for $30 \mathrm{~s}$. The 
samples were then diluted using nanopure water and plated, in triplicate, on R2A agar plates for CFU measurement.

\section{Contact angle measurements}

Contact angles, the direct measurement of surface hydrophobicity, were determined by the sessile drop method using a Ramé-Hart contact angle goniometer (Model 100-22, Ramé-Hart Instrument Co., NJ). One to $2 \mu \mathrm{l}$ of nanopure water were introduced into the cleaned and air dried membrane surface by a Gilmont (IL) microsyringe with a droplet diameter of $0.4-0.5 \mathrm{~mm}$. The images of water droplets were captured by a CCD camera and analyzed for contact angles (advanced and receding angles) using DROPimage Standard software (Ramé-Hart Instrument Co., NJ). The water droplet diameter on the virgin and air dried cleaned surfaces did not change; so, the captive bubble/drop method was not considered in this study for contact angle measurements.

Taniguchi and Belfort (2002) proposed a correction factor for the measured contact angle of UF membranes based on the membrane pore size. In this study, the correction factors for contact angles were not considered, because the pore sizes of the RO surfaces membranes $(\sim 2 \mathrm{~nm})$ were much smaller than those of UF membranes $(\sim 100 \mathrm{~nm})$. Ten to 15 different measurements of contact angles were carried out for each piece of cleaned membrane and its respective virgin membrane surface.

\section{AFM analysis}

For AFM analysis, membrane surface morphology and roughness of biofoulants on RO membranes were determined using a Multi-Mode AFM (Digital Instruments, Santa Barbara, CA). Imaging was performed in tapping mode with an etched silicon probe (TESP, Digital Instruments, Santa Barbara, CA). The TESP probes have a spring constant of $20-100 \mathrm{~N} \mathrm{~m}^{-1}$, a resonant frequency of $200-400 \mathrm{kHz}$, a nominal tip radius of $5-10 \mathrm{~nm}$, and a cantilever length of $160 \mu \mathrm{m}$. The root mean square (RMS) average of height deviations of roughness (Rq) and average roughness ( $\mathrm{Ra}$ ) of the TFC RO surfaces were measured and are discussed elsewhere (Khan, Stewart, et al. 2011). The average RMS values of $\mathrm{Rq}$ were calculated from 10 line scans on each AFM image. For each sample, five AFM images were taken and in each case the effective area was $25 \mu \mathrm{m}^{2}$.

\section{XPS analysis}

XPS analyses of RO membranes were performed on the virgin surfaces and also after cleaning the biofoulants to characterize the change in the mass percentage of the surface chemical elements due to the formation of biofoulants and their interactions. A 5400 PHI ESCA spectrometer (Physical Electronics, Eden Prarie, MN) with a non-monochromated aluminum $\mathrm{K} \alpha \mathrm{X}$-ray source $(h v=1486.6 \mathrm{eV})$ at a power of $250 \mathrm{~W}$ was used for the analysis. The acceleration voltage was $15 \mathrm{kV}$ and the current was 12-18 mA. The second and fourth derivatives of the spectrum were inspected to locate the positions of various peaks. The core level peaks were then successfully fitted with component peaks with a Gaussian-Lorentzian distribution. At these operating conditions, the penetration depth was $\sim 10 \mathrm{~nm}$ and the spot size analyzed was $\sim 300 \mu \mathrm{m} \times 700 \mu \mathrm{m}$.

\section{Results and discussions}

The most popular TFC RO membranes used in water treatment and seawater desalination have functional aromatic polyamide on the top layer prepared by an interfacial polymerization process (Petersen 1993; Rao et al. 1997). It is this layer with which the biofoulants interact.

Enzyme E \#1 is the mixture of Subtilisin protease and lipase. Lipase catalyzes the formation or cleavage (hydrolysis) of lipids (Afonso et al. 1999) and Subtilisin is a non-specific protease which initiates the nucleophilic attack on the peptide (amide) bond and degrades protein substrates (Bott et al. 1988; Bryant et al. 2009). Enzymes $\mathrm{E} \# 2$ and $\mathrm{E} \# 3$ are dextranase and PG based, respectively. Dextranase can hydrolyze or inhibit the synthesis of glucans and polysaccharide compounds (Subasioglu \& Cansunar 2010) and PGs degrade polygalacturonan, which is a significant carbohydrate component (Jones et al. 1972). Proteins, polysaccharides, and carbohydrates are the major components of the EPS that form the backbone of the biofouling, and the three enzymes used in this study hydrolyze three different targets. The efficiency and effect of enzymatic cleaning of RO biofoulants on the TFC surface are discussed below.

\section{Mode of action of enzymatic cleaning of $\mathrm{RO}$ membrane biofoulants}

To provide insight into the mode of action of the enzymes, top-view epifluorescence microscopy images of RO membrane biofoulants, cryo-sections of membrane biofoulants illustrating the biofoulant structures, and culturable cells in the biofoulants after enzyme exposure at different conditions were characterized and analyzed.

Visualization of live and dead cells in the top-view images of $R O$ membrane biofoulants

The orientation of live (green) and dead (red) cells (Figure 1) on the top of RO surfaces without enzyme treatment shows that the relative numbers of live and dead cells were comparable. This trend was observed in 


\begin{tabular}{lccc}
\cline { 2 - 4 } & \multicolumn{3}{c}{ Biofilm images after enzyme treatment for 18 h at different concentrations (ppm) } \\
\hline Biofoulant images without & 50 & 10 & 150 \\
enzyme treatment (control) & & & \\
\hline
\end{tabular}

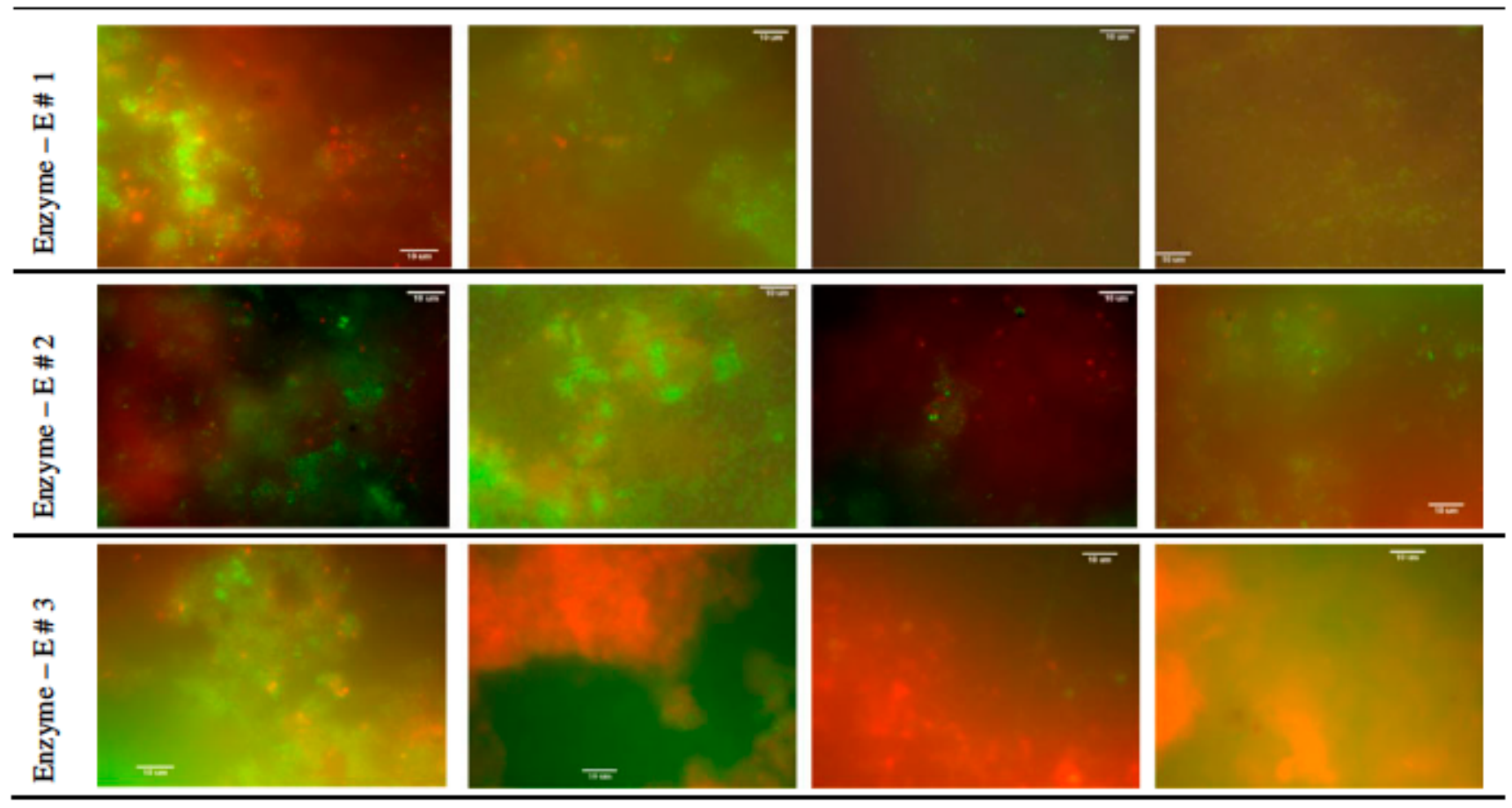

Figure 1. The representative biofoulant images on RO membrane surfaces with (enzymes E \#1, E \#2 and E \#3 at 50,100 and $150 \mathrm{ppm}$ concentrations) and without (positive control) enzyme treatment. The duration of the enzyme treatment of the biofoulant was $18 \mathrm{~h}$. The scale bar of these images is $10 \mu \mathrm{m}$. $p$ value was $0.01-0.05$.

the previous study using a similar type of membrane (Khan, Stewart, et al. 2011). The presence of dead cells may be the result of the impact of surface chemistry on cellular integrity, but since the same RO surfaces were used for the enzyme treatment this effect should not compromise the results. Cells mostly existed as clumps. In general, the numbers of cells were reduced as the enzyme concentrations increased from 50 to $150 \mathrm{ppm}$; but, cell numbers on the membranes treated by $\mathrm{E} \# 2$ and $\mathrm{E} \mathrm{\# 3} \mathrm{at} 50 \mathrm{ppm}$ for $18 \mathrm{~h}$ were higher than those treated by $\mathrm{E} \# 1$. The relative numbers of live/dead cells after enzyme E \#1 and E \#2 treatments were varied, but most of the remaining cells were alive. For E \#3 treatments the proportion of dead cells was higher.

At $150 \mathrm{ppm}$ and treatment for $36 \mathrm{~h}$ with enzymes E \#2

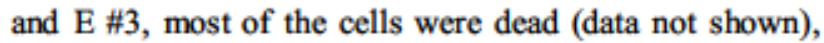
and this is similar to the results at a reduced incubation period $(18 \mathrm{~h})$. Treatment with enzyme E \#1 at a dose of $150 \mathrm{ppm}$ after $36 \mathrm{~h}$ resulted in the lowest number of cells but the majority of the remaining cells were alive. With the exception of enzyme E \#1, longer exposure times had greater biocidal effects. It was expected that each enzyme would react with the specific components of the biofilm matrix improving the biofoulant cleaning efficiencies.
However, it revealed that the biocidal effects of enzymes $\mathrm{E} \# 2$ and $\mathrm{E} \# 3$ disrupted the cell membrane of biofilm organisms causing more dead cells (PI positive). From these non-quantitative observations, it can be concluded that enzyme E \#1 at a dose of $100 \mathrm{ppm}$ and $18 \mathrm{~h}$ contact time was the best combination to remove cells.

The data shown in Figure 1 indicate that $\mathrm{E} \# 1$, a protease/lipase enzyme, was most effective in removing the biofouling. This suggests that proteins are a major component of fouling. The enzymes targeting polysaccharides and carbohydrates were either less effective at biomass removal or the proportions of these two components of EPS were lower than that of protein in the biomass. However, the enzyme that acts on PGs had more biocidal activity.

Additionally, the images suggest an optimum concentration for activity and the ratio between substrate and enzyme is important (Munoz-Aguado et al. 1996). Note that these enzymes were added on the top of the biofilm in the absence of shear stress or agitation; therefore, detachment of cells from the biofoulant matrix was truly dependent on the biochemical interactions between different reactive sites of these enzymes and the components of EPS and other organic molecules within the biofilm. 


\section{Quantification of biofoulant thickness and its structure}

Because of the limitations of direct microscopic observation, cryo-sectioning of biofoulants on RO surfaces and subsequent microscopy and image analysis were done to obtain more quantitative information about biofoulant thickness and its structure and the efficiency of enzymatic cleaning.

Figure 2 shows representative $5 \mu \mathrm{m}$ thick cryosection images of biofoulants with and without enzyme treatment at $100 \mathrm{ppm}$ and $18 \mathrm{~h}$ incubation. The arrows indicate the position of membranes underneath the biofoulants. Clusters of cells (live and/or dead) with hollow pockets denoted by circles on the figures were observed (Figure 2B). This is indicative of spatial variation in the porosity inside the biofouling (Lewandowski \& Beyenal 2005), which is related to the spatial distribution of diffusivity through the biofoulants and onto the membrane surfaces.

Line scans of these images were used to provide information on the distribution of live and dead cells in the biofouling layer and representative images are shown in Figure 2A, C, E, and G for the control sample and enzyme treatments by $\mathrm{E} \# 1, \mathrm{E} \# 2$, and $\mathrm{E} \# 3$, respectively. The skewness and intensity of distributions of the live/dead cell regions depends on the number of cells along the section of biofilm. The peaks of staining intensity for live cells (Figure 2A) (control sample) were closer to the biofilm-fluid interface than that for dead cells. In other words, dead cells were in closer proximity to the membrane surfaces and the live cells were at the top of the biofilm. The peak staining intensities of the dead and live cell regions were separated by $0.5-1.5 \mu \mathrm{m}$.

The average staining intensities of live and dead cells were the lowest when the RO biofoulants were treated with enzyme E \#1, which indicates that the protease-/ lipase-based enzyme not only hydrolyzed the proteins, but also disaggregated more cells from the biofilm matrix. This corroborates the microscopic observations. The peak staining intensities of the dead and live cell regions for enzyme E \#1 were separated by $0.4-0.9 \mu \mathrm{m}$, while those for enzymes E \#2 and E \#3 were separated by $0.6-1.2$ and $0.8-2.1 \mu \mathrm{m}$, respectively. The peaks of staining intensity of dead cells (Figure 2G) for enzyme E \#3 were closer to the biofilm-fluid interface than that for live cells, which also support the microscopic observations (Figure 1). It is evident from Figure 2 that during incubation the protease-/lipase-based enzyme penetrated the biofilm to a greater extent than other enzymes.

The average relative thickness of live and dead cell regions in the hydrated biofoulants is shown in Figure 3. For control samples live vs dead cell thicknesses are almost equal even though the biofilm samples on RO surfaces were grown in different reactors, indicating the reproducibility of biofoulant formation on the RO surfaces. The accumulated thicknesses of live and dead cells were similar after treatment by enzyme E \#1, which is in good agreement with the images obtained with the microscope (Figure 1). However, for enzymes E \#2 and $\mathrm{E} \# 3$, the accumulated thicknesses of live and dead cells differ from the surface-based microscopic observations. The respective thicknesses of live and dead cells are similar for both enzymes, but higher than that of treatment by enzyme E \#1.

With an increase in the enzyme concentration up to $100 \mathrm{ppm}$, the detachment of biofilms also increased. At concentrations above $100 \mathrm{ppm}$, there was no significant change in thickness for any of the enzymes. In another study (Xu \& Liu 2011), 25\% of the fixed biomass on a nylon membrane was removed when $10 \mathrm{ppm}$ D-tyrosine was used, which was increased to $60 \%$ at a $500 \mathrm{ppm}$ dose. In other words, a 50-fold increase in enzyme leads to a $35 \%$ increase in biomass removal. In the present study, only $100 \mathrm{ppm}$ of $\mathrm{E} \# 1$ removed $>90 \%$ of the biofoulants. An increase in incubation period (from 18 to $36 \mathrm{~h}$ ) for E \#2 and E \#3 did not improve removal of live and dead cells, but E \#1 showed more removal of biofoulants at the longer time period. Overall, the biofoulant removal efficiency of $\mathrm{E} \# 1$ was the highest, followed by $\mathrm{E} \# 2$ and then $\mathrm{E} \# 3$. It must be noted that these observations are relative and only appropriate for the experimental conditions tested; other experimental conditions may give different results. However, the methods described herein show the relative comparisons between the enzymes.

\section{Cellular viability in the biofoulants after enzyme exposure}

In a previous study (Khan, Takizawa, et al. 2011), chemical cleaning of fouled membrane could not bring the membrane resistance to its virgin condition even though the flux after chemical cleaning was restored to a level similar to that of pure water flux. Ideally, the enzyme should remove the EPS components of biofoulant. Inactivation of the organisms could be a secondary effect; therefore, it is important to determine if the treatments simply remove the biofouling or if there is loss of viability in addition to removal. Figure 4 shows the culturability of cells that were removed from the surface of the membranes during enzyme treatment. For comparison, the culturable cell counts in the scraped and suspended biofilm that had not been exposed to the enzymes varied from $1.31 \times 10^{9}$ to $2.52 \times 10^{11} \mathrm{CFU} \mathrm{m}^{-1}$ (equivalent to $1.02 \times 10^{10}-1.95 \times 10^{12} \mathrm{CFU} \mathrm{cm} \mathrm{cm}^{-2}$ of membrane surface). However, the maximum culturable cell count in the suspended biofilm exposed to the enzyme was $\sim 0.5 \times 10^{6} \mathrm{CFU} \mathrm{m}{ }^{-1}$. After enzymatic cleaning of biofoulants, there was still some biofilm present on the RO surfaces (Figure 3); therefore, it is not possible to 

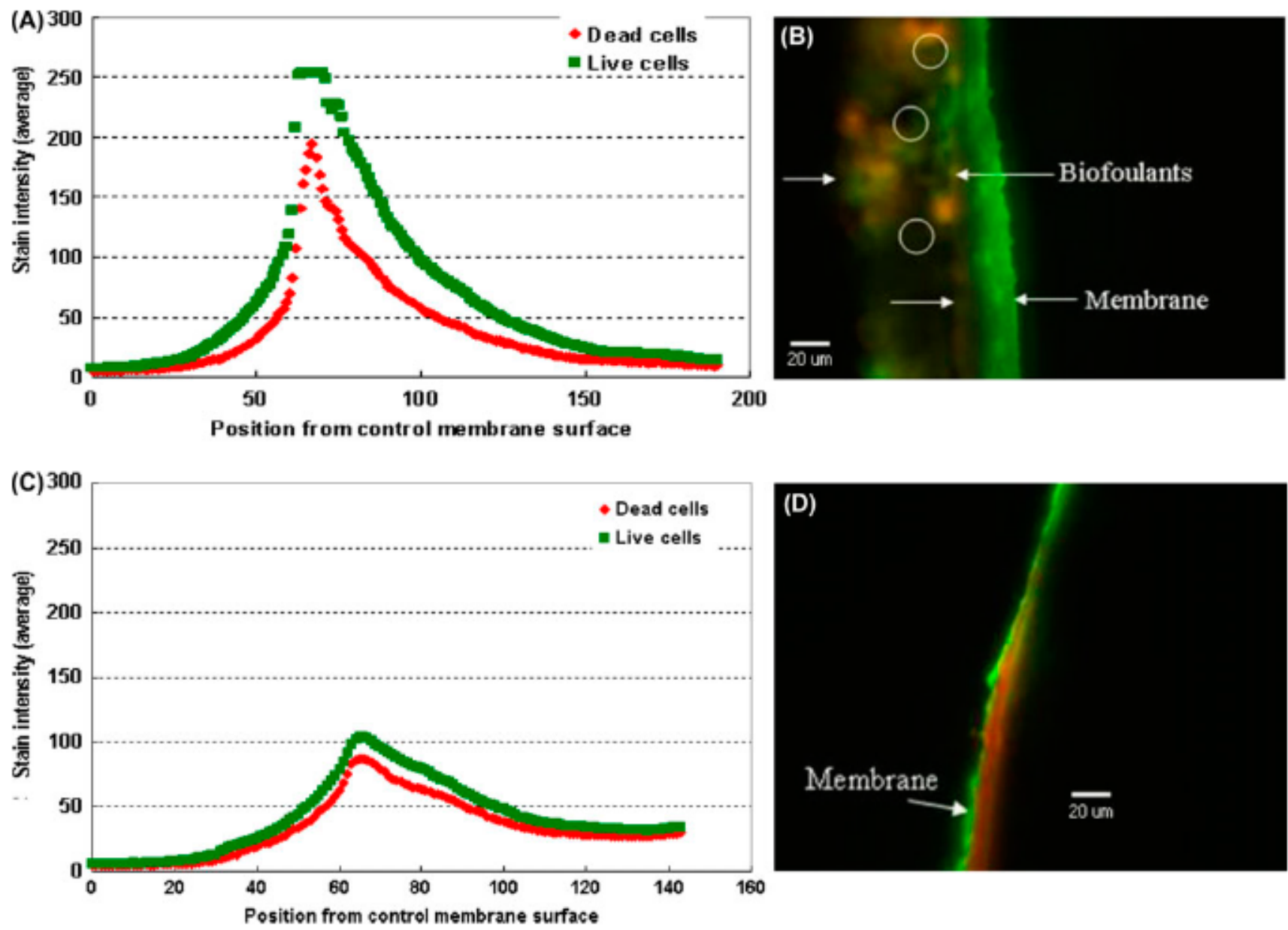

Figure 2. Representative $5 \mu \mathrm{m}$ thickness cryo-sections of (B) control RO membrane with biofoulants; and (D), (F) and (H) RO membranes after the enzyme treatment by $\mathrm{E} \# 1, \mathrm{E} \# 2$ and $\mathrm{E} \# 3$, respectively, after staining by the Live/Dead BacLight ${ }^{\mathrm{m}}$ Bacterial Viability Kit. The profiles of live and dead cell regions in the biofilms on (A) RO without enzyme treatment; and (C), (E) and (G) on the membranes after enzyme treatment using a $100 \mathrm{ppm}$ dose and $18 \mathrm{~h}$ incubation in enzymes $\mathrm{E} \# 1, \mathrm{E} \# 2$ and $\mathrm{E} \# 3$, respectively, after line-scanning the respective cryo-sections. The arrows indicate the position of membrane top layer surface and circles show the hollow pockets inside the biofoulant.

compare how many cells inside the biofilm lost their viability during the incubation with enzymes at different conditions.

The culturability was reduced by more than 5 logs even at the lowest concentration of $50 \mathrm{ppm}$ and the shortest incubation period $(18 \mathrm{~h})$. Counts were reduced further when the concentrations of enzymes and the incubation period were higher. This suggests that the concentration of these enzymes is a more important factor than the incubation period in reducing the cellular culturability. These data directly corroborate with the surface-based microscopic observations; with the increase in the enzyme concentrations, the number of live cells was reduced (Figure 1), and the live cell concentration dictates the cellular culturability. The effect of treatment on culturability was comparable for each dose and incubation time for all enzymes used in this study.

\section{Characterization of the effects of enzymes on RO membrane surface properties}

RO membrane surface roughness, morphology, hydrophobicity, and the mass percentage of chemical composition were investigated and quantified before and after biofoulant formation and also after enzyme cleaning.

\section{Biofoulant morphology and effects of enzymatic cleaning} of biofoulant to revive the RO surface roughness

Surface morphology is important in controlling the accumulation of biofouling (Elimelech et al. 1997; Flemming 1997; Flemming et al. 1997), and at the same time biofouling can change the surface morphology and roughness (Kwak \& $\mathrm{Ihm}$ 1999). Rougher membranes have a higher tendency for fouling by natural organic matter and soluble microbial products (Park et al. 2005). 

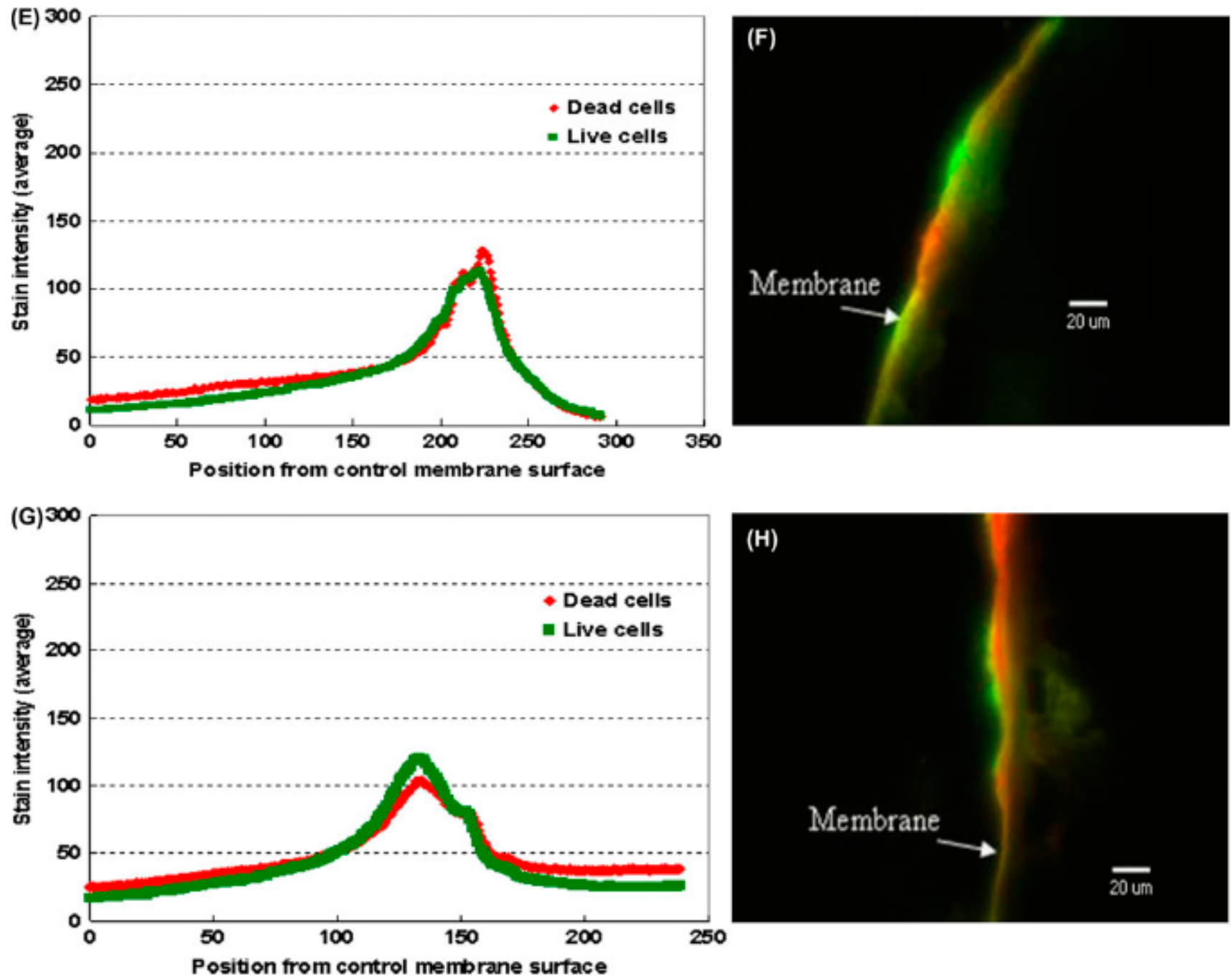

Figure 2. (Continued)

Once membrane surfaces are exposed to the biofoulants, their physico-chemical properties are altered to some noticeable extent (Ferjani et al. 2000; Park et al. 2005; Khan et al. 2010) and those properties cannot be resorted completely even after appropriate cleaning (Park et al. 2005). In the authors' previous work, when the biofouled TFC RO surface was cleaned physically (using nanopure water and a soft rubber scrubber), the roughness wasstill $48 \mathrm{~nm}$ greater than that of the virgin membrane. After enzymatic cleaning, the changes in roughness were insignificant for E \#1 while the other enzymes had varied effects (Figure 5). Further details on the AFM images of the biofoulants on RO membrane surfaces without enzymatic treatment and after treatment by enzyme E \#1 using different conditions are shown in Supplementary Figure S2. The standard error (SE) of the mean values of $\mathrm{Ra}$ and $\mathrm{Rq}$ varied from 1.01 to $3.01 \mathrm{~nm}$.

The protease-/lipase-based $\mathrm{E} \# 1$, at the concentration of $100 \mathrm{ppm}$ and the incubation period of $18 \mathrm{~h}$, was optimum to restore the TFC RO surface roughness. When the concentration was increased, the roughness was reduced. RO surface roughness was reduced significantly at most of the combinations of dextranase-based $\mathrm{E}$ \#2 (exception at $150 \mathrm{ppm}$ dose for $36 \mathrm{~h}$ ) and for all combinations of PG based E \#3. This observation suggests that during enzymatic cleaning conditions should be optimized to maximize the cleaning while maintaining the initial roughness ( $\sim$ virgin conditions), which controls the membrane flux and fouling of the TFC surface layer of the RO membrane.

Effects of enzymatic cleaning on the TFC surface hydrophobicity

Advanced water contact angle $\left(\theta_{\mathrm{w}}\right)$ is a direct measure of surface hydrophobicity of a dry surface. Biofouling on RO surfaces can increase the $\theta_{\mathrm{w}}$ (Khan et al. 2010; Khan, Stewart, et al. 2011) and these changes are associated with 


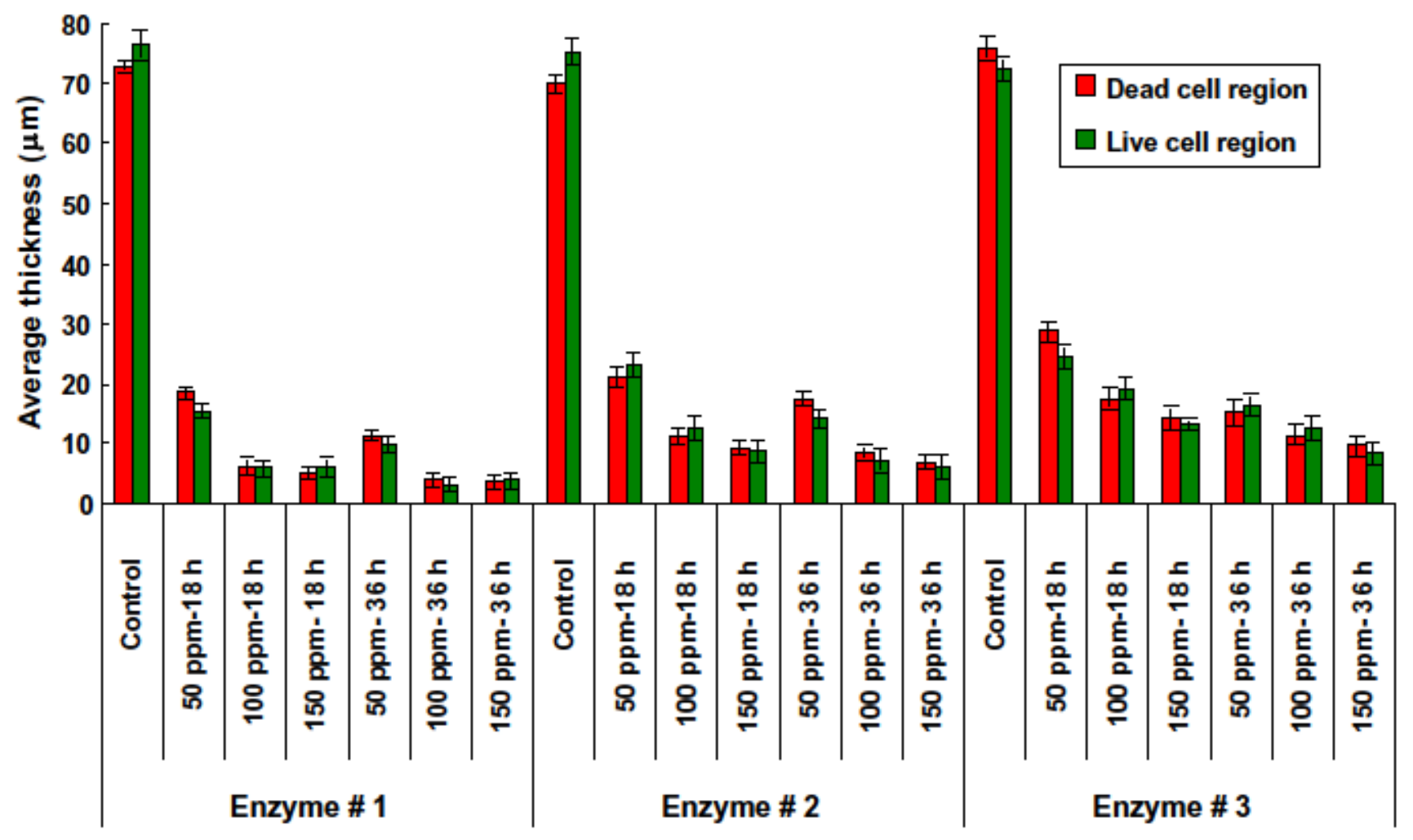

Enzyme treatment conditions

Figure 3. Cryo-sectioning of the membranes with and without enzyme treatment. The control indicates the membrane biofilm without enzyme treatment. The effects of different doses and enzyme incubation times are significant. Error bars show the \pm SE of the mean values, which varied from 0.78 to $2.47 \mu \mathrm{m}$. The $p$ value was $<0.05$.

the loss of membrane permeability due to the attached biofoulant macromolecules (Herzberg \& Elimelech 2007). The cause of the changes in hydrophobicity due to biofouling is not well understood. Hypothetically, the bacterial cells in the biofouling layer act as a particulate fouling layer hindering back-diffusion of salts from the membrane surface, thus elevating the osmotic pressure near the membrane surface. Moreover, the EPS component of the biofouling layer seems to mainly increase the biofilm hydraulic resistance to permeate flow (Flemming 2002; Chong et al. 2008). In practice, the coupling effect of increases in osmotic pressure and hydraulic resistance cause a decrease in permeate water flux loss and this effect does not follow a simple gradient along the biofilm. Interestingly, increases in osmotic pressure and hydraulic resistance are the results of hydrophobicity changes in the RO surfaces due to fouling. Field observations have shown that once biofoulants accumulate on membrane surfaces initial membrane productivity or hydrophobicity cannot be restored even after chemical (Li \& Elimelech 2004) and concentrated salt (Lee \& Elimelech 2007) cleaning of biofouled surfaces.

The $\theta_{\mathrm{w}}$ of the virgin RO membrane was $\sim 30^{\circ}$, and after enzymatic cleaning of biofoulants only E \#1 at
$100 \mathrm{ppm}$ and $18 \mathrm{~h}$ incubation could restore the $\theta_{\mathrm{w}}$ of the RO surface to its virgin condition (Figure 6). Even though $\mathrm{E} \mathrm{\# 2}$ and $\mathrm{E} \# 3$ reduced the thickness of live and dead cells significantly, they could not restore the $\theta_{\mathrm{w}}$ to the virgin condition. This indicates that dextranase and PG based enzymes reacted with the TFC surface of the RO membrane while the protease-/lipase-based enzyme did not. In a previous study (Khan et al. 2010), biofouled TFC RO surfaces were physically cleaned and there was a $\sim 50^{\circ}$ of $\theta_{\mathrm{w}}$ increase from its virgin condition. This study, without filtration, also shows that after enzymatic cleaning of biofouled TFC RO surfaces their hydrophobicities $\left(\theta_{\mathrm{w}}\right)$ increased from $2^{\circ}$ to $30^{\circ}$; however, the incremental changes would likely be different if the study was performed in filtration mode.

Changes in RO surface chemical compositions and their recovery by enzymatic cleaning

For XPS, each element has a characteristic binding energy associated with each core atomic orbital, ie each element will give rise to a characteristic set of peaks in the photoelectron spectrum at kinetic energies determined by the photon energy and the respective binding energies. 


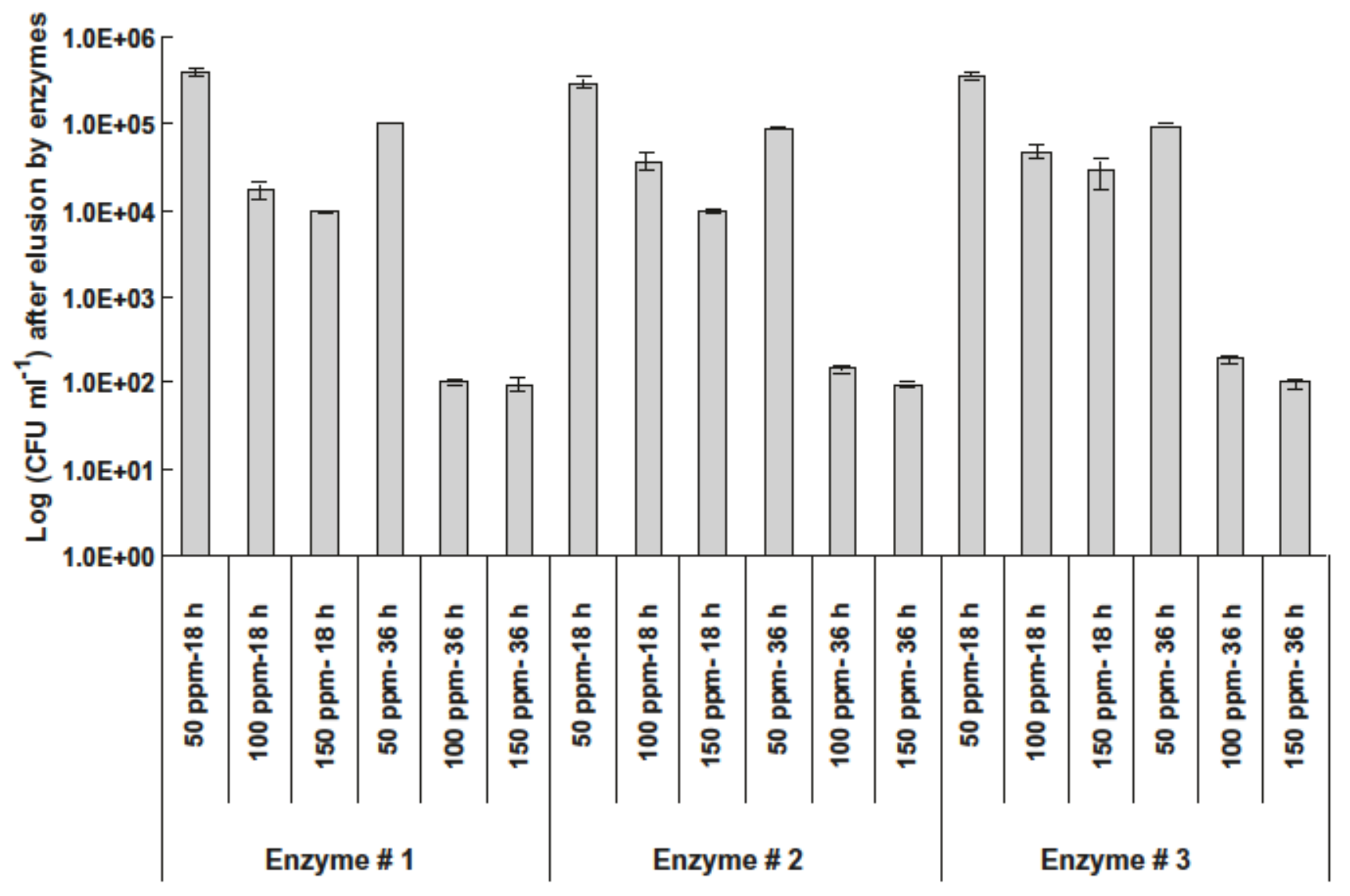

\section{Enzyme treatment conditions}

Figure 4. Culturable cell counts of microorganisms in suspension after enzyme treatments and cell dispersion. The cell counts in suspension of the control samples (without enzyme treatment) varied from $1.31 \times 10^{9}$ to $2.52 \times 10^{11} \mathrm{CFU} \mathrm{ml}^{-1}$. Error bars show the $\pm \mathrm{SE}$ of the mean values. The area of membrane swatch was $\sim 1.29 \mathrm{~cm}^{2}$ and collected cells in the biofoulants on the RO swatch were dispersed and resuspended into $10 \mathrm{ml}$ of nanopure water. The $p$ value was $0.01-0.05$.

The presence of peaks at particular energies, therefore, indicates the presence of a specific element in the sample under study (Ferjani et al. 2000). Supplementary Table S1 provides the mass percentages of important chemical elements on the TFC RO surfaces at their virgin conditions and after physical (control) and enzymatic cleaning of biofoulants. Along with biofilm accumulation, in most cases inorganic accumulation or the changes in the mass percentage of chemical elements were also seen. Increases in calcium, aluminum, and silica after cleaning the biofilm could be due to the particulate fouling included in the biofilm or the formation of calcium aluminum silicates, which was not confirmed in this study. Representative XPS plots of the RO membrane after treatment with $\mathrm{E} \mathrm{\# 1}$ at $50 \mathrm{ppm}$ for $18 \mathrm{~h}$ incubation at room temperature are shown in Supplementary Figure S3.

After exposure to the variable environment in the RDRs and physical cleaning, the carbon (C) content on the virgin TFC RO surfaces was reduced by $29 \%$ (Supplementary Table S1). After enzyme treatment, the C content was lower than after physical cleaning of membrane surfaces. Only treatment with E \#1 at $100 \mathrm{ppm}$ and for $18 \mathrm{~h}$ incubation could potentially restore the $\mathrm{C}$ content to virgin conditions. The mass percentage of nitrogen $(\mathrm{N})$ and oxygen $(\mathrm{O})$ mostly increased when the biofouled surfaces were cleaned physically and by enzymatic treatment. The overall changes in these elements were the lowest in the case of $\mathrm{E} \# 3$ treatments. The phosphorus (P) content did not increase after enzymatic cleaning of biofoulants, which was higher (at least five times) when the biofoulants were cleaned physically. In a parallel study, the biofoulants with RO surface were incubated inside the enzyme solutions for $48 \mathrm{~h}$ and no significant change in the mass percentage of chemical elements of the RO surfaces was observed compared with those for a $36 \mathrm{~h}$ incubation time (data not shown). Other investigators (Yu et al. 2013) used dichloroisoc- 


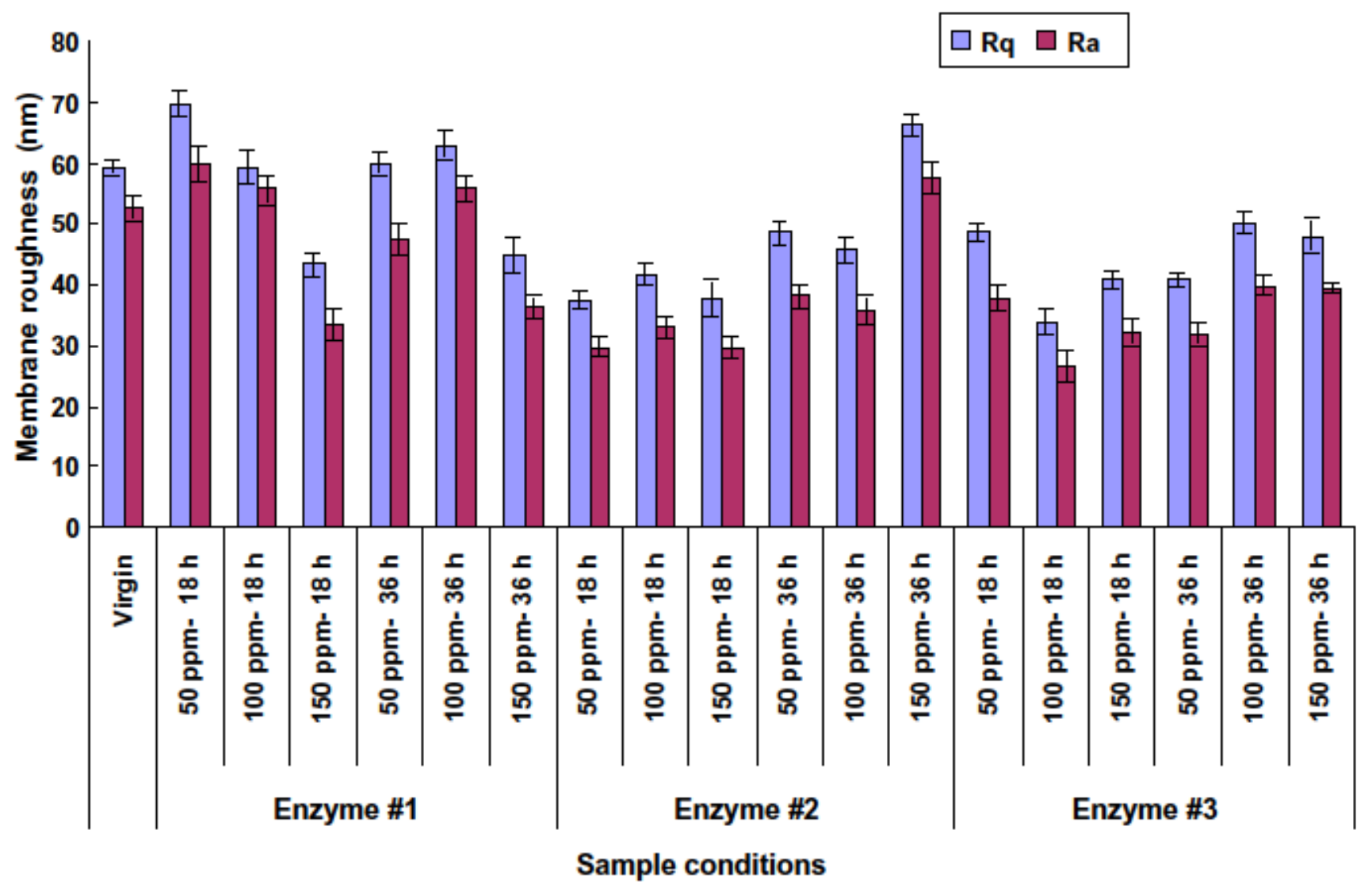

Figure 5. The RMS average of height deviations of roughness $(\mathrm{Rq})$ and average roughness (Ra) of virgin and biofouled RO membrane surfaces after cleaning by enzymes $\mathrm{E} \# 1, \mathrm{E} \# 2$ and $\mathrm{E} \# 3$. Error bars show the $\pm \mathrm{SE}$ of the mean values, which varied from 1.01 to $3.01 \mathrm{~nm}$ for $\mathrm{RO}$ membrane roughness. The $p$ value was $<0.05$.

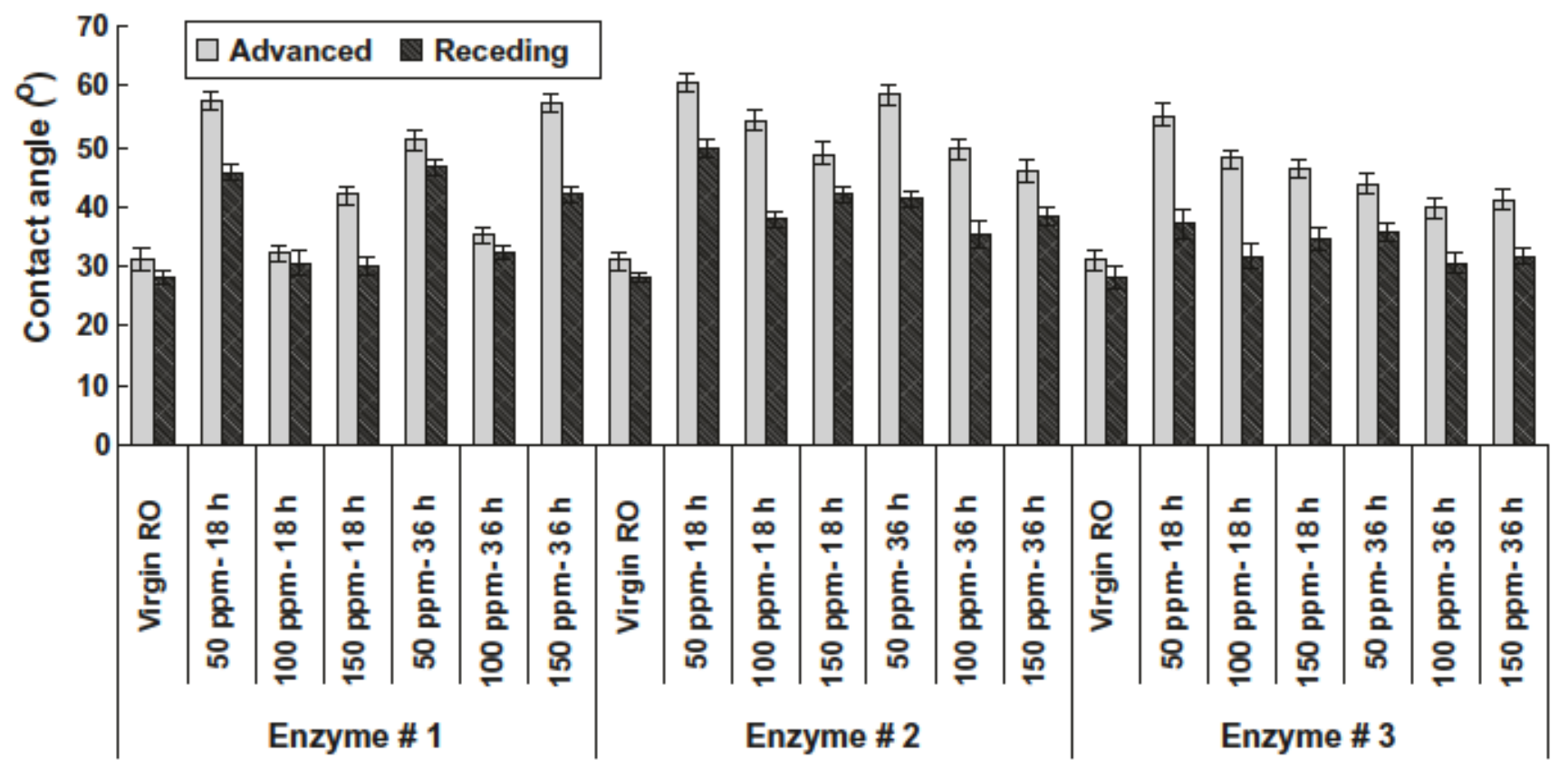

Figure 6. Average advanced and receding contact angles of RO membrane surfaces: untreated (virgin surface) or treated by enzymes $\mathrm{E} \# 1, \mathrm{E} \# 2$ and $\mathrm{E} \# 3$. Error bars show the $\pm \mathrm{SE}$ of the mean values, which varied from $0.94^{\circ}$ to $2.43^{\circ}$. The $p$ value was $<0.05$. 
yanurate (DCC) to control biofoulants on RO surfaces and confirmed with XPS and ATR-FTIR analyses that at low concentration and a longer exposure time (dose: contact time $-300 \mathrm{mg} \mathrm{l}^{-1}: 50 \mathrm{~h}$ ) DCC had very similar effects on biofoulant control compared with those at higher concentration and a shorter exposure time (dose: contact time $-5,000 \mathrm{mg}^{-1}: 3 \mathrm{~h}$ ). However, further investigation is required to confirm this observation using the enzymes used in this study.

The increase in $\mathrm{O}$ and decrease in the $\mathrm{C}$ contents on the cleaned surfaces could be due to the presence of EPS, which have high $\mathrm{O}$ to $\mathrm{C}$ ratios $(\mathrm{O} / \mathrm{C})$ (Arthur 1989; Riedl et al. 1998). After cleaning the RO surfaces enzymatically, the $\mathrm{O} / \mathrm{C}$ varied from 0.11 to 0.25 , from 0.13 to 0.36 , and from 0.13 to 0.39 for enzymes E \#1, $\mathrm{E} \# 2$, and $\mathrm{E} \# 3$, respectively. These values suggest that the accumulation of EPS on the RO surface treated by enzyme E \#1 was the lowest. The protease-/lipase-based enzyme hydrolyzes protein substrates; therefore, major components in the EPS in biofoulants appear to be proteins, which corroborates with the microscopic observations. Interestingly, the $\mathrm{O} / \mathrm{C}$ ratio was the lowest $(0.11)$ for $\mathrm{E} \mathrm{\# 1}$ at $100 \mathrm{ppm}$ and $18 \mathrm{~h}$ incubation. In parallel studies, the virgin membrane swatches without biofilm were also soaked in the three enzyme solutions for $18 \mathrm{~h}$ and $36 \mathrm{~h}$ at room temperature in the dark. The mass percentages of important chemical elements did not change significantly from the virgin conditions (data not shown).

The $\mathrm{O}$ and $\mathrm{N}$ mass percentage ratios for virgin $\mathrm{RO}$ surfaces were $\sim 1$. This ratio was $\sim 1.1-2.2$ times higher for the RO membranes after enzymatic cleaning. These significant changes in the $\mathrm{O}$ and $\mathrm{N}$ mass percentage ratios were likely due to the interaction of different macromolecules in biofoulants with the membrane (Zhou et al. 2005). It is important to note that the penetration depth of the X-ray beam into the sample was $\sim 10 \mathrm{~nm}$ and the chemical elements of cleaned membrane surfaces (in Table S1) may also include the aromatic TFC layers of the RO membranes.

\section{Conclusions}

The biofouling of TFC RO membranes during the production of safe potable water is one of the major obstacles in their use and the efficient cleaning of biofoulants without altering or damaging the membrane surface properties remains as a challenge. The cost for chemical waste disposal and management after membrane foulant cleaning is a major concem in membrane filtration industries, but altemative and safe approaches to cleaning biofouled membranes are limited. The enzymes used in this study were synthesized from the environmental isolates of different bacterial species and they are environmental friendly. In this study, the authors demonstrated the mode of action of different enzyme-based cleaning agents and their effects on TFC RO membrane surfaces.

According to the functions of the enzymes, the protease-/lipase-based enzyme hydrolyzed proteins, and dextranase- and PG-based enzymes acted upon polysaccharide compounds and carbohydrate components of the EPS in the biofoluants. The action of these enzymes also provided insights into the composition of the biofouling, indicating that the protein content in the biofoulants was the highest. The protease-/lipase-based enzyme disaggregated more cells from the biofilm and also more effectively penetrated the biofilm during treatment. During treatment, most of the interactions may be considered to be of the protein-membrane type. However, it is possible that this enzyme adsorbed on the membrane surface where it hydrolyzed the proteins and protein fragments, thus inducing a self-cleaning mechanism. Once the RO surface was biofouled, physical cleaning could not restore its surface properties; however, at an appropriate concentration and an optimum incubation period, the protease-/lipase-based enzyme restored the RO surface properties almost to their original condition.

The results also showed that the dose of enzymes and incubation period are the key factors for efficient removal of biofoulants. All of these enzymes significantly affected cellular viability. These studies under conditions of no flow provide the basis for understanding removal mechanisms and suggest that this approach will be effective under field conditions. Further study of the enzymatic chemistry and working conditions of the enzymes is necessary for providing a promising TFC RO membrane biofouling cleaning approach.

\section{Acknowledgements}

This research was supported by the Novozymes A/S. The authors would like to thank Dr David G. Whitten, Editor-inChief of Langmuir and Professor at the Department of Chemical and Nuclear Engineering of the University of New Mexico, for his valuable suggestions and comments on this report. The authors would like to thank Dr David J. Moll and Dr William E. Mickols of the Dow Chemical Company for proving the polyamide aromatic thin-film composite (TFC) RO (Dow BW30) membranes used in this study.

\section{References}

Afonso C, Tulman E, Lu Z, Oma E, Kutish G, Rock D. 1999. The genome of Melanoplus sanguinipes entomopoxvirus. J Virol. 73:533-552.

Allie Z, Jacobs EP, Maartens A, Swart P. 2003. Enzymatic cleaning of ultrafiltration membranes fouled by abattoir effluent. J Membr Sci. 218:107-116.

Ang WS, Lee SY, Elimelech M. 2006. Chemical and physical aspects of cleaning of organic-fouled reverse osmosis membranes. J Membr Sci. 272:198-210. 
Argüello MA, Álvarez S, Riera FA, Álvarez R. 2003. Enzymatic cleaning of inorganic ultrafiltration membranes used for whey protein fractionation. J Membr Sci. 216:121-134.

Argüello MA, Álvarez S, Riera FA, Álvarez R. 2005. Utilization of enzymatic detergents to clean inorganic membranes fouled by whey proteins. Sep Purif Technol. 41:147-154.

Arthur SD. 1989. Structure-property relationship in a thin film composite reverse osmosis membrane. J Membr Sci. 46:243-260.

Bott R, Ultsch M, Kossiakoff A, Graycar T, Katz B, Power S. 1988. The three-dimensional structure of Bacillus amyloliquefaciens subtilisin at $1.8 \mathrm{~A}$ and an analysis of the structural consequences of peroxide inactivation. J Biol Chem. 263:7895-7906.

Brunner G, Okoro E. 1989. Reduction of membrane fouling by means of an electric-field during ultrafiltration of protein solutions. Berichte Der Bunsen-Gesellschaft - Phys Chem Chem Phys. 93:1026-1032.

Bryant MK, Schardl CL, Hesse U, Scott B. 2009. Evolution of a subtilisin-like protease gene family in the grass endophytic fungus Epichloë festucae. BMC Evol Biol, 9:168.

Chen V, Li H, Li D, Tan S, Petrus HB. 2006. Cleaning strategies for membrane fouled with protein mixtures. Desalination. 200: 198-200.

Chong TH, Wong FS, Fane AG. 2008. The effect of imposed flux on biofouling in reverse osmosis: role of concentration polarization and biofilm enhanced osmotic pressure phenomena. J Membr Sci. 325:840-850.

Costerton WJ, Lewandowski Z, Caldwell DE, Korber DR, Lappin-Scott HM. 1995. Microbial biofilms. Annu Rev Microbiol. 49:711-745.

Donlan RM. 2002. Biofilms: microbial life on surfaces. Emerg Infect Dis. 8:881-890.

El-Dahshan ME. 2001. Corrosion and scaling problems present in some desalination plants in Abu Dhabi. Desalination. 138:371-377.

Elimelech M, Zhu X, Childress AE, Hong S. 1997. Role of membrane surface morphology in colloidal fouling of cellulose acetate and composite aromatic polyamide reverse osmosis membranes. J Membr Sci. 127:101-109.

Ferjani E, Mejdoub M, Roudesli MS, Chehimi MM, Picard D, Delamar M. 2000. XPS characterization of poly(methylhydrosiloxane)-modified cellulose diacetate membranes. J Membr Sci. 165:125-133.

Flemming HC. 2002. Biofouling in water systems - cases, causes and countermeasures. Appl Microbiol Biotechnol. 59:629-640.

Flemming H-C. 1997. Reverse osmosis membrane biofouling. Exp Therm Fluid Sci. 14:382-391.

Flemming H-C, Schaule G, Griebe T, Schmitt J, Tamachkiarowa A. 1997. Biofouling - the Achilles heel of membrane processes. Desalination. 113:215-225.

Hasson D, Semiat R. 2006. Scale control in saline and wastewater desalination. Isr J Chem. 46:97-104.

Herzberg M, Elimelech M. 2007. Biofouling of reverse osmosis membranes: role of biofilm-enhanced osmotic pressure. J Membr Sci. 295:11-20.

Herzberg M, Kang S, Elimelech M. 2009. Role of extracellular polymeric substances (EPS) in biofouling of reverse osmosis membranes. Environ Sci Technol. 43:4393-4398.

Hong SK, Elimelech M. 1997. Chemical and physical aspects of natural organic matter (NOM) fouling of nanofiltration membranes. J Membr Sci. 132:159-181.
Iritani E, Mukai Y, Kiyotomo Y. 2000. Effects of electric field on dynamic behaviors of dead-end inclined and downward ultrafiltration of protein solutions. J Membr Sci. $164: 51-57$.

Jones TM, Anderson AJ, Albersheim P. 1972. Host-pathogen interactions IV, studies on the polysaccharide-degrading enzymes secreted by Fusarium oxysporum f. sp. lycopersici. Physiol Plant Pathol. 2:153-166.

Khan MMT, Stewart PS, Moll DJ, Mickols WE, Burr MD, Nelson SE, Camper AK. 2010. Assessing biofouling on polyamide reverse osmosis (RO) membrane surfaces in a laboratory system. J Membr Sci. 349:429-437.

Khan MMT, Stewart PS, Moll DJ, Mickols WE, Nelson SE, Camper AK. 2011. Characterization and effect of biofouling on polyamide reverse osmosis and nanofiltration membrane surfaces. Biofouling. 27:173-183.

Khan MMT, Takizawa S, Lewandowski Z, Jones WL, Camper AK, Katayama H, Kurisu F, Ohgaki S. 2011. Membrane fouling due to dynamic particle size changes in the aerated hybrid PAC-MF system. J Membr Sci. 371:99-107.

Kimura K, Hane Y, Watanabe Y, Amy G, Ohkuma N. 2004. Irreversible membrane fouling during ultrafiltration of surface water. Water Res. 38:3431-3441.

Kwak SY, Ihm DW. 1999. Use of atomic force microscopy and solid-state NMR spectroscopy to characterize structure property-performance correlation in high-flux reverse osmosis (RO) membranes. J Membr Sci. 158:143-153.

Lee S, Elimelech M. 2007. Salt cleaning of organic-fouled reverse osmosis membranes. Water Res. 41:1134-1142.

Lewandowski Z, Beyenal H. 2005. Biofilms: their structure, activity, and effect on membrane filtration. Water Sci Technol. 51:181-192.

Li Q, Elimelech M. 2004. Organic fouling and chemical cleaning of nanofiltration membranes: measurements and mechanisms. Environ Sci Technol. 38:4683-4693.

Maartens A, Jacobs EP, Swart P. 2002. UF of pulp and paper effluent: membrane fouling-prevention and cleaning. J Membr Sci. 209:81-92.

Munoz-Aguado MJ, Wiley DE, Fane AG. 1996. Enzymatic and detergent cleaning of a polysulfone ultrafiltration membrane fouled with BSA and whey. J Membr Sci. 117:175-187.

Park N, Kwon B, Kim IS, Cho J. 2005. Biofouling potential of various NF membranes with respect to bacteria and their soluble microbial products (SMP): characterizations, flux decline, and transport parameters. J Membr Sci. 258:43-54.

Petersen RJ. 1993. Composite reverse osmosis and nanofiltration membranes. J Membr Sci. 83:81-150.

Platt S, Nystrom M. 2008. Cleaning of fouled ultrafiltration (UF) membrane by algae during reservoir water treatment. Desalination. 220:267-272.

Puspitasari VL, Rattier M, Le-Clech P, Chen V. 2010. Performances of protease and amylase cleaning for microporous membranes used in wastewater applications. Desalin Water Treat. 13:441-449.

Rao AP, Desai NV, Rangarajan R. 1997. Interfacially synthesized thin film composite RO membranes for seawater desalination. J Membr Sci. 124:263-272.

Ridgway HF, Flemming H-C. 1996. Membrane biofouling. In: Mallevialle J, Odendaal PE, Wiesner MR, editors. Water treatment membrane processes, membrane biofouling. New York (NY): MoGraw-Hill; p. 6.1-6.62.

Riedl K, Girard B, Lencki RW. 1998. Influence of membrane structure on fouling layer morphology during apple juice clarification. J Membr Sci. 139:155-166. 
Rosen MJ. 1989. Surfactant and interfacial phenomena. 2nd ed. New York (NY): Wiley.

Speth TF, Gusses AM, Summers RS. 2000. Evaluation of nanofiltration pretreatments for flux loss control. Desalination. 130:31-44.

Stoodley H-L, Stoodley P. 2002. Developmental regulation of microbial biofilms. Curr Opin Biotechnol. 13:228-233.

Subasioglu T, Cansunar E. 2010. Optimization of culture conditions and environmental factors of dextranase enzyme produced by Paecilomyces lilacinus. Hacettepe J Biol Chem. 38:159-164.

Taniguchi M, Belfort G. 2002. Correcting for surface roughness: advancing and receding contact angles. Langmuir. $18: 6465-6467$.

Tarazaga CC, Campderros ME, Padilla AP. 2006. Physical cleaning by means of electric field in the ultrafiltration of a biological solution. J Membr Sci, 278:219-224.

Thurman EM. 1985. Organic geochemistry of natural waters. Boston (MA): Martinus Nijhoff/Dr W. Junk Publishers.

von Zumbusch P, Kulcke W, Brunner G. 1998. Use of alternating electrical fields as anti-fouling strategy in ultrafiltration of biological suspensions - introduction of a new experimental procedure for crossflow filtration. J Membr Sci. 142:75-86,

Weng YH, Chaung-Hsieh LH, Lee HH, Li KC, Huang CP. 2005. Removal of arsenic and humic substances (HSs) by electroultrafiltration (EUF). J Hazard Mater. 122:171-176.

Wiesner MR, Aptel P. 1996. Mass transport and permeate flux and fouling in pressure-driven membrane processes. In: Mallevialle PEO, Wiesner MR, editors. Water treatment membrane processes. New York (NY): MoGraw-Hill; p. 4.1-4.30.

Xu H, Liu Y. 2011. D-amino acid mitigated membrane biofouling and promoted biofilm detachment. J Membr Sci. 376:266-274.

Yu J, Baek Y, Yoon H, Yoon J. 2013. New disinfectant to control biofouling of polyamide reverse osmosis membrane. J Membr Sci, 427:30-36.

Zhou Y, Yu S, Liu M, Gao C. 2005. Preparation and characterization of polyamide-urethane thin-film composite membranes. Desalination. 180:189-196. 